\title{
Regulating Unregulated Corruption in Ethiopia: Private and Religious Sectors under a Glance
}

\author{
Filata Gigiso Boroje \\ School of Law, Hawassa University, Hawassa, Sidaama, Ethiopia \\ Email: filatagigiso@gmail.com
}

How to cite this paper: Boroje, F. G. (2019). Regulating Unregulated Corruption in Ethiopia: Private and Religious Sectors under a Glance. Beijing Law Review, 10, 505-525.

https://doi.org/10.4236/blr.2019.103031

Received: March 27, 2019

Accepted: June 2, 2019

Published: June 5, 2019

Copyright $\odot 2019$ by author(s) and Scientific Research Publishing Inc. This work is licensed under the Creative Commons Attribution International License (CC BY 4.0).

http://creativecommons.org/licenses/by/4.0/

\begin{abstract}
As corruption is a big concern of every society in the world, nations have been exerting utmost effort to combat, if possible, or at least to minimize its prevalence. Such efforts of controlling corruption necessarily involves preventive and corrective measures, such as enhancing ethics amongst the individual members of the society and prosecuting individuals who have been found involved in such acts. Those preventive and corrective measures are often taken by states in the public sectors only in exclusion of other sections, such as religious institutions and private sectors. This trend, however, has allegedly affected effectiveness of states' anticorruption efforts as corrupt behaviors and acts in those social institutions go unregulated; thereby providing fertile ground for prevalence of corruption in those sects that later can intrude into public sect. Understanding this, some international and regional anticorruption instruments tend to advise state parties to deal with private sect corruption. As a result, countries have started to extend anticorruption hands to crucial area of private sectors, good example being the recent Ethiopian anticorruption proclamation that has extended state's anti-corruption hand to some institutions in the private sectors. The proclamation, however, excludes all religious institutions and some of a private sector from the ambit of the state regulation, allegedly affecting the state's plan of combating corruption. Accordingly, this paper, through doctrinal legal research method combined with some empirical considerations, tries to articulate problems associated with unregulated corruption and also tries to justify a state intervention in unregulated area.
\end{abstract}

\section{Keywords}

Unregulated Corruption, State Intervention, Public Sector, Private Sector, Religious Institutions 


\section{Introduction}

Corruption has continued as the biggest concern of the globe, with a special attention being given in the developing world where its prevalence is so vast. Initial attempts of anticorruption have principally focused on a corrupt practices and behaviors in the public sector only. Later on, however, it was realized that combating corruption requires dealing with corruption in sects of the society, other than the public sector. Accordingly, anti-corruption movements have been extended to private sectors, and there is also an effort to further extend it to all societal institutions. Being the case, the scope of anticorruption institutions in Ethiopia also reveals that the Ethiopia's anticorruption efforts are limited to public and some private sectors only, leaving vast majority of the societal sects unregulated. Aiming at exposing this anticorruption gap of Ethiopia, this paper tries to briefly address unregulated corruption in private sector and religious institutions. Believing that unregulated corruption would pose a big problem in a state's effort to combat corruption, it is argued that a state, through appropriate institutions, should deal with corruption in all sectors of the society.

The paper is divided into five sections. The first part briefly states the definitional problem associated with corruption, approaches taken to address this problem by different writers, and the definition adhered to by this paper.

The second part of the paper is devoted for discussion of the scope of the anticorruption institutions of Ethiopia. To that effect, detail discussion is provided as to sects of the society that are expressly included, impliedly included and expressly excluded from the purview of the anticorruption institutions and laws of the Country.

Third part also tries to shed a light on the two important sects of the society, i.e. private and religious sects, corruption committed in these sects, both in elsewhere and at national level. This part presents a modest finding of the research by stating some of the corruptions committed in these sects in the studied area; calling for and justifying a state intervention.

Finally, the fourth section provides concluding remarks about corruption in these sects.

\section{Defining Corruption}

There are many different ways of defining corruption, yet there is not a single, agreed upon and reliable definition of it (Raj Kumar, 2008). It is a commonplace that there is no single, authoritative, comprehensive and universally accepted definition of corruption (Tessema \& Koen, 2017). According to Kumar (Ibid), the problem of defining corruption is writ large as demonstrated by the fact that the United Nations Convention against Corruption (UNCAC) itself did not define corruption but rather preferred to define and criminalize certain offences constituting corruption. Moreover, because corruption takes a variety of forms, it hardly is possible to formulate a generic definition which embraces all the species and peculiarities of problem (Tessema \& Koen, 2017). The definitional 
problem in fact, becomes important as the ways it is defined affects the ways in which it is fought (You \& Khagram, 2005). Defining corruption as the abuse of public trust for private gain (Ibid, emphasis added) for instance limits anticorruption moves within the purview of public sector. Searching for more inclusive definition, at least to include some private institutions, it was defined as a behavioral problem (Asian Development Bank/ADB definition as cited by Kumar, 2008). However, this definition still excludes religious institutions, and therefore, corruption is defined as a human rights violation (Kumar, 2004).

Having the above discussed definitional problem in mind, we dwell on definition of corruption as a behavioral problem, as this definition is more acceptable by many scholars (Ochulor \& Bassey, 2010) and better explain the problem of corruption. Based on etymological meaning of the word "corruption", Ochulor, et al. (Ibid) defines it as-to decompose or to disintegrate, to lose value, to become putrid and useless. From this, Ochulor et al. (Ibid) concluded that corruption is an ethical and moral problem, i.e. ethical or moral decomposition, disintegration. It involves behavior on the part of officials in the public and private sectors (Emphasis added), in which they improperly and unlawfully enrich themselves and/or those close to them, or induce others to do so, by misusing the position in which they are placed (Raj Kumar, 2008).

\section{The Scope of Anticorruption Laws of Ethiopia}

The scope of any law is determined by the definition the law adopts about the subject matter it primarily deals with. Anticorruption laws of FDRE, however, do not define corruption. Instead, they preferred to list acts of corruption (FDRE, Proc. No. 441/2005 and Proc. No. 881/2015). Accordingly, the scope of FDRE anticorruption laws cannot precisely be determined from their definition of corruption. In the previous anticorruption laws (FDRE, Proc. No.s 235/2001 \& 433/2005), the scope was determined by looking into objectives, powers and responsibilities of the Commission and from definitions of some terminologies, such as public bodies and public enterprises. Those laws provide for three basic objectives of the Commission, namely, ethics education, corruption prevention, and law enforcement (Tamyalew, 2010).

The Commission has also been granted with powers of promoting ethics and anti-corruption education, preventing corruption offenses and other improprieties; and exposing, investigating, and prosecuting corruption offenses and improprieties (Ibid). The Commission, however, was empowered to exercise these powers in public offices and public enterprises only with the exception of ethics promoting power which it may arguable exercise in other sects. Therefore, the Commission's scope was limited to prevent, expose, investigate and prosecute corrupt acts in this sector only. This scope has excluded private sectors, religious institutions and other sects of society from the ambit of the Commission.

Noting some of the problems associated with such a limited scope, the anticorruption law has been amended (FDRE, Proc. No. 883/2015) in 2015 and one of the 
reasons for such amendment was expanding the Commission's power to corrupt acts in private sector that has direct connection with public funds (FDRE, Proc. No. 881/2015). The scope of this recent anticorruption law of the FDRE can be envisaged from two angles, i.e. from the provisions that define its scope by including and excluding institutions and sectors of society under the Commission's power.

\subsection{Exclusive Provisions}

The exclusion provision excludes many public organizations, such as religious institutions, political party, international organization and "edir" or other similar traditional or religious organizations (Ibid). One of these excluded institutions, the religious institutions, call for attention on the basis of the scope of this paper.

Religious organization is defined by the proclamation as an organization or institution of worship established by the followers of a religion to organize or to promote their religion (Ibid, Art. 2(9)). But it does not include the organizations established under the religious organization with intent to achieve objectives of a charity (Ibid). This definition, however does not address the issue of business activities engaged in by religious organizations. As it will be seen from discussion in the coming section, it is natural to categorize such businesses under the private sector, and may be included under the Commission's purview following the "source-purpose" test. It is also equally valid to argue that business activities of religious organizations are also excluded from the ambit of the Commission's power as it is not expressly included as such. At this juncture, therefore, it is clear that all religious organizations are excluded from the reach of the Commission, except the case where it engages in charity activities. The issue of business activities of religious organizations remains undetermined.

To sum up, the law expressly excludes many organizations and institutions and hence, anticorruption commission does not exercise its powers in these institutions and organizations. This provision, therefore, inter alia, clearly excludes religious institutions, i.e. the religious sector from the Commission's reach.

\subsection{Inclusive Provisions}

On the other hand, the inclusion provision empowers the Commission to deal with corruption in the public office (Art. 2(1), public enterprises (Art. 2(3) and public organizations (Art. 2(4) (Ibid). The issue of public office and public enterprises inclusion is not the new one. The newly introduced one is inclusion of public organizations. The law defines public organization as-any organ in the private sector which in whatever way administers money, property or any other resource collected from members, or from the public or any money collected for the benefit of public which includes appropriate company-(Ibid, Art. 2(4), Emphasis added). Appropriate companies and resource collected for public interest are also defined in Art. 2 (6) and (7) respectively.

Appropriate company means any private limited company which is established through the contribution of shares by public organizations and includes joint venture established by such company in association with others (FDRE, 
Proc. No. 881/2015, emphasis added).

Resource collected for the benefit of the public is also defined as any money, property or resource that is collected with the intent to support, assist, encourage or develop the whole or a section of the community or obtained in any way with such intent and administered or utilized by a charity or association (Ibid).

According to Art. 2(8) (Ibid), a charity means an institution, which is legally registered and established exclusively for charitable purposes and gives benefit to the public (FDRE, Proc. No. 881/2015). From these definitional provisions, we may develop guiding tests to identify whether a given private organ is included under the Commission's power. The two tests are "source of fund test" and the "purpose of collection test", or in short, it may be called the "Source-Purpose Test".

\subsection{The "Source-Purpose Test"}

To determine a proper scope of the above stated inclusive definitions, we may apply the "source-purpose" test. The "Source" test states that any organization that has public as a source of its resources (be it money or other resources) is a public organization. Public source may include members of the organization, non-member contributors or individual donations (so far the purpose of such individual donation is to benefit a public at large).

The "Purpose" test on the other hand states that any organization that owns and administers resources for benefit of the public (public purpose of resource use) are public organizations. Any money, property or resource that is collected with the intent to support, assist, encourage or develop the whole or a section of the community is said to be for benefit of the public. Irrespective of its sources, therefore, if any organization owns or administers any resource with such intent, such organization may be called public organization.

From this, we may conclude that the "source-purpose" test doesn't require existence of the cumulative requirement, It suffices to categorize an organization as a public when one of the two requirements meets, i.e. the company is public when either its resource source is a public, or is intends to use it for the public purpose. Therefore, private limited company, share company, charity organizations, and others are properly under the Commission's reach. Though the definition seems to limit applicability of this law to private limited companies and joint ventures established by them, however, the afore mentioned definition of the public organization (art. 2 (4)) is too broad that it includes all organs that administer resources collected from members or from public that aim at public benefit.

On the contrary, if any organization has private entities or individuals as sources of its resource which it intends to exploit for private use, it fails to meet the "source-purpose" test requirements; and therefore, is purely private organization, being excluded from the reach of the Commission. Therefore, the scope of the current anticorruption law of Ethiopia does not include partnerships and 
other sole proprietorships (individual entrepreneurs) as these businesses are purely private one and do not satisfy any of the "source-purpose" test requirements. That means the Commission or any other appropriate organ does not have an authority to detect, investigate and prosecute corrupt acts in these entities.

In conclusion, corrupt behaviors and acts, if any, in the religious institutions and in purely private sector institutions-as stated here above-are excluded from the reach of the Commission. Therefore, corruption in these institutions fall under "unregulated corruption" in Ethiopia. Valid question at this point is, therefore, not about sectors in which corruption is unregulated; it, rather, is, is there corrupt acts and behaviors in those societal sectors which are excluded from the Commission's purview of power? The next two topics deal with this issue very briefly by raising experiences across the world.

\section{Unregulated Corruption in Private and Religious Sectors}

The previous section has clearly stated the scope of anticorruption commission of Ethiopia. In that, it was made clear that the scope of this commission is limited to dealing with corruption mainly in public sector and in private sector that have public at large either as their source of resource or as ultimate beneficiary of the resources. Except this partial address, there are many sectors in the society that either are not clearly put under the Commission's purview or those that are clearly excluded from its scope. Exhaustive analysis of all those sectors that remained out of the shadow of anticorruption institutions may require much more finance, time and effort. Accordingly, this study is purposely made to focus on the uncovered part of the private sector, and the religious sector. Therefore, based on the experiences of other countries, and results obtained from the studied area, corruption in unregulated part of the private sector and in the religious sectors, together with justifications for state intervention is discussed under this section.

\subsection{Corruption in Private Sectors}

Needless to say, corruption can be and is committed routinely in both the private and public sectors (Tessema \& Koen, 2017). Private sector corruption is perpetrated by private sector actors within the private sector. Private sector corruption is an abuse of entrusted power within and/or between the economic zones under the ownership of private entities. It is known also as private-to-private corruption because both the corrupter and corrupted are private entities or individuals. Private sector corruption (Ibid).

Tessema and Koen (2017) have noted that private sector corruption is as widespread as public corruption. In his definition of corruption as impropriety or unlawful enrichment of officials both in public and private sectors, Kumar (2008) also admits existence of private sector corruption. Moreover, R. D. R. (1960), also confirmed existence of rampant private sector corruption, and ar- 
gues for the need to control such nongovernmental corruption. Painter (2006) also wrote about corruption in business (private corruption) and its interrelation with corruption in political system, thereby affirming existence of private sector corruption.

In addition to individuals' efforts, by now, private sector corruption has become an issue of international, regional, national and local level concern and is dealt with as such. United Nations Convention against Corruption (UNCAC), the African Union Convention on Preventing and Combating Corruption (AU Convention) and the Southern African Development Community Protocol against Corruption (SADC Protocol) and many other international and regional legislations have clearly addressed the case of private sector corruption (Tessema \& Koen, 2017). The prevention and criminalization provisions of UNCAC explicitly address private sector corruption after an intense debate among member states (Ibid). The debate and the focus given by member states clearly show the problematic level of private sector corruption. Even USA, the one argued against criminalization of private sector corruption, did not argue about its existence, rather argued legality only of dealing with this corruption (Ibid).

\subsection{Private Sector Corruption in Ethiopia}

At national level, existence of corruption in private sector is also admitted by the Ethiopian legislature where it extends the power of the Commission to deal with corruption in businesses-called public organizations (FDRE, Proc No. 881/2015). Many have agreed that exclusion of purely private business from the current legal extension does not imply absence of corruption in those businesses; it rather is exclusion made on the basis of administrative and financial feasibility. Private sector corruption, in the study area take a variety of forms, including bribery, embezzlement, trading in influence, trading information, abuse of power and favoritism. Among others, this research has identified the following forms of private business corruption in the studied area.

\section{Bribery of the Agent or Employee of Another}

According to R. D. R. (1960), this type of corruption may take many forms, such as bribing an agents or employees in charge of purchasing or hiring, bribing labor representatives and commercial bribery. Having these forms of corruption, an effort was made to detect whether any of these forms of corruption has existed in the study area. The result has affirmed that there are number of ways in which employees of others are corrupted. Corrupting experts to compromise the quality, supply continuity or to trade in information are often committed forms. Suppliers of similar goods or services often deal with high level experts of the competing business for the above mentioned purposes. Some business persons stated that it is widespread practice to bribe high level experts, even to the extent of offering better payment if the one is willing to get employed in their business.

The other form of corrupting employees of another is by bribing sales-persons 
of another employer. This is common in butcher businesses where salespersons are often bribed by customers. The same form of corruption happens where things exact amount of which cannot be precisely pre-determined are offered. This form of corruption, especially what is termed as "commercial bribery" may be committed either directly, or in the form of gifts or entertainments or even in the form of subsidies to the retailer (R.D.R,). Likewise, this research has also identified these forms are used in the study area, though a common form is the direct bribery.

\section{Corruption in Sport Activities}

The effort made to study football and taekwondo sport activities (as the two are engaged in by many youth) show that there are many corrupt acts in these sporting activities. Some football clubs repeatedly claim that bigger clubs with better financial stand often win the championship by bribing the competent clubs' players, coaches and arbitrators. The same allegations are made by the taekwondo clubs in the city. On the other hand, taekwondo trainees have repeatedly accused club coaches for their mischievous dealings. Taekwondo coaches intentionally fail to upgrade and certify their trainees who want to graduate from the club unless the trainee pays good amount of bribes.

\section{Bribes Given to Receive Better Services}

Many participants witnessed rampant corrupt acts in small service delivery businesses paid by customers to receive better services and treatments, Good example in this regard is hotel services. Waiters/waitresses in hotels serve the one who better pays money which is far much more than an ordinary services tip. Those who pay this bribe receive better services including priority. This form of corruption is becoming common in the study area.

\section{Corrupt in Private Sector Recruitment}

Corruption in the form of nepotism and favoritism is common in hiring and firing process in the private businesses studied. Many express their feeling that amount of a money one can offer to a given recruitment committee determines the chance of being recruited. A candidate who can offer highest bid has always a good chance of being recruited irrespective of her academic performance or relevant experiences to the post. Nearly in all private recruitment, either a money offer, or being managers'/owners' keen, or sexual relationship work well than formal requirements. This form of private business corruption is becoming common phenomenon in the studied area.

\section{Corruption in the Form of Unfair Trade Dealings}

Competing businesses relationship in the studied area is often based on unfair competition. In a few scenarios only they make clandestine agreements to determine fictitious prices of basic commodities. The first relationship of unfair competition is manifested in many ways, including trading in information from the competing business via corrupting high level expert, disseminating false information about competing business by using agents paid for this purpose, false tax evasion accusations made through unanimous informants designed by other competing business, absconding a key employee of a competing business and 
many others. False defamation of competing business is also another form of unfair competition, and this one is common in local restaurants and bar services. All these forms of unfair competition involve corruption as a competing business uses direct or indirect benefits paid to key individuals involved in those activities.

The other way of corruption in businesses unfair competition form is rather a dubious dealings by suppliers and retailers of basic commodities. These business men make a secret agreement to fix fictitious higher price of basic commodities. One may argue that this kind of dealings cannot be termed as a corruption. However, the wider definition of corruption/rent seeking being advocated these days may capture these forms of undeserved enrichments. This form of dealings/corruption is common in supplies of sugar, oil, meet and meet products and in many similar businesses.

Corrupting Representatives of a Labor Unions/Employees Representatives

Purely private businesses (other than public organizations) are flourishing in the study area following establishment of Industry parks and encouragement schemes extended by the state to entrepreneurs. These businesses hire number of employees who have not form formal labor unions. These employees/workers, however, elect their representatives to deal with their employers in different issues. Often, workers blame their representatives of being corrupted by their employers to suppress workers' demands. This kind of practice is being expanded where workers are abused in many ways by their employers, and rendered voiceless by corrupt representatives. Abuses include sexual abuses, unpaid overtime works, un-proportional punishments for faults committed by employees and many others. The situation is exacerbating as a result of expansion of purely private business in the studied area.

The above discussion makes it clear that there is rampant corruption in purely private sector, and it is not regulated by anticorruption laws and institutions. Like its public sector counterpart, private sector corruption has severe damaging consequences for the development and good governance of affected countries. In a word, corruption, in both its public and private aspects has an injurious impact. However, it has not been given the attention it deserves, unlike its public sector counterpart. This calls for the need to control uncontrolled corruption in this sector.

\subsection{Corruption in Religious Institutions}

Corruption exists not only in business, politics and NGOs but also in churches and in the religious institutions of all religions (Stückelberger, 2010). All world religions condemn corruption in their holy texts and all religions are at the same time affected by unethical practices. But the corruption mechanisms vary with the different structures of the religions, with their status in society, and with the corrupt environments in which they find themselves (Ibid). Following existence of corruption in all religious institutions, efforts have been made to determine a 
relationship between religion and religiosity on one hand and corruption on the other (Marquette, 2010; Faleye, 2013; Adebimpe \& Ayodeji, 2014; Stückelberger, 2010).

Most of these studies have concluded that religious principles and values have not contributed to minimize corruption. A study made across different countries with various religious institutions show that existence of religion and religiosity does not contribute to corruption control (Marquette, 2010). On the contrary, it is found that existence of religion and strong religiosity has probably contributed to prevalence of corruption (Ibid). The possible explanation forwarded is that in many countries, few of the population members are perpetrators (of the corruption crimes) and majority of the population, who is submissive to their religious life, do not tend to question those few corrupts (Ibid). This silence of the majority of the religious persons has provided corrupts a favorable ground as they are not questioned. This is one way where religion indirectly encourages corruption by turning majority of population uninterested or less interested in corruption matters.

The second way in which corruption is exacerbated by religion is where people turn from their traditional way of belief to other religions. Most importantly, empirical study shows that people get more corrupt when they change their religion from the traditional to Christianity and other religions (Ibid). Moreover, studies across countries also show that a country with people of high religiosity is more corrupt than the country with less number of religious people (Ibid). These facts show that there is corrupt acts and behaviors in the religious institutions.

Studying the case of Nigeria, Adebimpe \& Ayodeji (2014) conclude that churches, and prophets in Nigeria are highly corrupt. Stückelberger (2010) also states about corrupt practices in churches in India, Tanzania, Ghana and other countries. In 2006 Theodor Ahrens conducted a representative survey among 41 staff members of German mission societies on their perception of corruption in partner churches, and it was found out that $95 \%$ see corruption in partner churches as a very widespread phenomenon (Stückelberger, 2010). As to Islam, according to the Transparency International (TI), 40\% of the studied respondents in the Middle East and North Africa region reported paying bribes in the previous 12 months. Since $85-100 \%$ of the population in the countries of the Middle East and North Africa are Muslim it means that corruption among Muslims is widespread (Ibid). Stückelberger (Ibid) also further discusses existence of corruption in Hinduism and Buddhism as well. His conclusion is very clear, that corruption exists in all religions.

Corruption in religious institutions may be committed by both religious leaders as well as followers. Leaders commit corruption in the form of collecting undue money from followers (in the form of so called "bribing God" preaching; that urges attendants to "give" in order to "receive". "Give and you will be given" principle). The other way in which religious leaders commit corruption is by misusing religious institutions affiliated charity money. Followers also commit 
corruption in many ways. The most important one is the desire to receive blessings that one has not labored to. This is what some writers call the "Gospel of Prosperity'. This desire of mass attendants is paving the way to wide spread preaching of the "Gospel of Prosperity" by preachers. The problem of this type of corrupt demands that mass attendants carry their corrupt behavior to their secular life and get involved in corruption to satisfy their lust that has been created in religious places through the "Gospel of Prosperity. The fact that most Nigerians are religious persons, and yet corruption is wide spread in Nigeria (Adebimpe \& Ayodeji, 2014) affirms this allegation. Corruption also often happens in religious institutions during election for religious leadership. This is another instance where followers and leaders of religious institutions can engage in corrupt practices.

What could be causes for corruption in religious institutions? Among many causes of corruption in religious sector are greed interest of religious leaders (Faleye, 2013), shallow, superficial, noisy and devoid (Adebimpe \& Ayodeji, 2014), lack of control (as indicated by $78 \%$ of studied sample populations), poverty of the recipients (49\%), lack of consciousness about legal matters (29\%), and personal greed and lack of character (20\%) (Stückelberger, 2010).

Why is corruption in religious institutions an issue? As a corruption everywhere, corruption in religious institutions undermine sustainable development of a given country (Faleye, 2013), affects funding by religious affiliated charity as it results in loss of trust between donors and their partners (Stückelberger, 2010), it makes religious institution to lose its appeal as a promoter of right values and spiritual standing, thereby resulting in loss of confidence (Adebimpe \& Ayodeji, 2014). Most importantly, prevalence of corruption in religious institutions makes anti-corruption efforts useless. Corruption is often defined as an ethical and moral problem, i.e. ethical or moral decomposition, disintegration (Ochulor \& Bassey, 2010). Following this definition, prevalence of corruption in any section of a society shows prevalence of ethical and moral decomposition or disintegration of individual members, to which religious sector cannot be an exception. Therefore, prevalence of corruption in religious institution simply means prevalence of corrupt individual members. It assures existence of many individuals with corrupt mentality. People with this corrupt behavior, therefore, will have a vast unregulated space to exercise corruption, to get involved in corrupt acts without any fear. Then, corrupt behaviors and acts would become common and tolerable, and even sometimes legitimate as there is no one condemning these acts in the sector. Corrupt behaviors and acts will become proper way of worship and religious exercises, and the followers would also think it is a proper component of their religion dogma. Good examples, in this regard are the so called "Gospel of Prosperity" and "Corrupting Devine". These types of corruptions are perceived by followers of the religion as proper ways of worshipping, and they perceive as the preacher of such gospel is rightly acting. They even fiercely oppose anyone who condemns these corruptions. In this and many other ways, religious institutions will turn into a place where corruption is freely exer- 
cised by majority of the followers and religious leaders. This contributes to rampant corruption in the sector.

One way or the other, persons in religious sector have many social, economic and political interactions in public as well as private sectors. In their transactions and interactions in these sectors, they easily carry their corrupt behavior and acts to these sectors, where a government attempts to control corruption. Given the number of persons from religious institutions; and also given an existence of rampant corruption in this sector, corrupt behavior and acts they bring to public and private sector would be difficult to manage. Specifically, uncontrolled corrupt behavior in the religious sector can turn the government effort of creating ethical society useless. Put in other words, we can say there are two opposing institutions dealing with corruption; a state, criminalizing and penalizing corrupt acts and behaviors in public and some private sectors on one hand; and religious institutions, promoting and legitimizing corrupt behaviors and acts in the religious sector on the other. While one fights against corruption, the other promotes and legitimizes it. While one attempts to deter, the other encourages corruption, and the promoting institution-religious sector-have even more capacity to catch minds of the people. This creates the problem when the space of interaction for members of these institutions becomes common. This is to say, persons in the religious institutions-where corruption is promoted-are also persons that act in public and some private sectors where corruption is criminalized. The same individual faces two different spaces. In that case, persons with less rationality will automatically favor corruption they have been exposed to in their religious arena. The most rational person only would analyze and try to reason out. In that case, she is left with the choice of adjusting her behaviors and acts in accordance with either corruption or purity, for she cannot remain with two personality, corrupt and pure, at the same time. In making such adjustments, she considers many factors, inter alia, her financial needs, her political interest, the promise she received in her religion place, legal sanctions, and social status. At this juncture, it may require further research to conclude which way, the purity or the corruption, a given person may choose. Three considerations in this case is very important.

One: The promise she receives in his faith, most often, the promise of receiving "unexpected blessings" that may come across her way at unexpected time and place. A person with this kind of prophecy, for sure, assumes any opportunity for corruption as the fulfillment of the "prophecy" she received; and may decide to get in corrupt acts. Shrugging such opportunity off may be regarded as undermining the prophetic promise, or in an extreme case, as disobedience of the divine orders. This way, a person can adjust himself with corruption.

Secondly: A person may not, at all, think that such acts are corrupt one. In the religious institutions, where acts like "gospel of prosperity" and "god bribing" are considered as legitimate, a person is told and have accepted that these acts-corruption-are legitimate. If confronted with similar or related corrupt acts, they would automatically accept such acts as correct deed. This way, they 
get involved in corruption in the private and public sectors. This is another possible way via which rampant corruption in religious institutions can be carried into other sectors.

Thirdly, financial status of a person can be another factor that affects a person's self adjustment decision. In most cases, a person with financial constraints who has been exposed to rampant corruption in religious institutions may decide in favor of involving in corrupt acts despite of legal restrictions. For she has been experiencing corruption in her religion place, she would not be much worried about its consequences. Rather, she would be tempted by the opportunity she is placed with. This way, a person may carry her corrupt behavior from religious to public or private sector. These are a few instances where corrupt acts and behaviors in religious institutions may be carried into secular life, thereby affecting a state's effort of fighting against corruption.

According to the UN, every person has a right to live in corruption free environment. "Environment" in this sense includes all sectors of a society in which a person lives. Religious sector, hence, is one of such sectors expected to be free of corruption. Therefore, existence of wide-spread corruption in religious sector violates this right of persons to live in corruption free society. This is, therefore, another important instance where uncontrolled corruption in religious sector affects anti-corruption efforts of a state.

\subsection{Religious Corruption in Ethiopia}

Religious corruption is widespread in the studied area. This study has not make an effort to make comparative analysis among different religions. It has summarized information obtained from followers of and some leaders from many religious institutions, and from non-religious people. The result shows that the following religious corruptions are common in this area.

\section{Cheating followers via Gospel of Prosperity and Bribing God type of Corruption}

Many religious leaders preach Gospel of Prosperity that aims at convincing religious followers to be faithful to religious leaders and to Creator in order to receive divine blessings. Through this type of preaching, religious leaders strongly convince their followers to be faithful to orders of the leader and/or God. Once they put their followers in the state of mind where followers accept what their leaders say, those leaders preach about "giving to God" and "Man of God" in order to be blessed with all worldly blessings. Followers, through bribing god technique, are fiercely influenced to obey their religious leaders and pushed to contribute to the religious works without reservations. Expecting many blessings instead, followers happily contribute what they can, and in many cases, what even they cannot (beyond their financial capacities). They without hesitation pay what they are asked for by their leaders as envisaged in her preaching. This practice is common in many institutions led by people who call themselves "prophets" or "Man of God". Many agree that this kind of practice is robbing many innocent followers, followers suffering from incurable diseases 
who are left with no other option, but to trust what their leaders say. People who highly believe in miracles also are cheated by this type of practice even if they have a good command of worldly knowledge. In short, this kind of act is affecting many people, literate or illiterate. On the contrary, many respondents said that these kind of religious leaders are seen being changed very fast in terms of quality of their life. Many of them get rich within short period of time, while many followers suffer from life instability following their unbalanced contributions to their prophets. Many religious leaders earn huge amount of unaccounted money which is not subjected to taxation. Almost all prophets in the study area have satellite TVs through which they preach the above mentioned type of gospel. Their ownership of satellite TVs has maximized their potential of reaching followers inside the country and abroad, whereby enlarging their revenue sources. There are handful prophets engaged in similar activities in the study area. This shows that corruption in the form of "Gospel of Prosperity" and "Bribing God" is rampant in this area, that it is becoming common practice of many religious institutions.

\section{Favoritism}

Religious followers in almost all religious institutions blame religion leaders for their discriminatory approach among followers. Followers with better financial status, socially accepted and those hold powers in a government offices are favored by religious leaders. In return, those individuals reward those leaders in number of ways, including offering money, in-kind benefits, undue respects and so on. Less influential persons are given lesser attention in provision of religious services. Engagement programs, children baptism programs, individual prayer programs, individual gospel services programs, visitations by religious leaders, provision of seats during Sunday and other services are instances where differential treatments are made among the "haves" and "have-nots". Relatively poorer followers accuse their religious leaders of receiving undue benefits from relatively richer followers. This form of religious corruption is deep rooted and commonly manifested in all religious institutions in the study area.

\section{Unfair Competition Type of Religious Corruption}

This type of corruption is recently being committed following emergence of many "prophets" in protestant religion. These prophets, in order to have as many followers and contributors as possible, compete with other prophets. This competition is often made by bribing a key individual of the competing prophet. It also involves some strong individuals who can persuade/influence many followers. This competition usually involves personal conflict between prophets and defaming one another.

\section{Pride and/or Trust Seeking}

In this form of corruption, religious leaders (recently calling themselves "prophets') strongly influence and corrupt individuals proximate to them. They provide incentives to these individuals in many forms and, in return, ask them to serve them honestly. This honest service includes advocating for the prophet, serving as his agent (to convince Christians to accept the prophet as a true one), 
worship services (especially, providing strong support to what the "prophet" says during his preach), acting as if they have been blessed, cured, rescued through "prophet's" prayer, including witnessing that before the mass attendants. These proximate individuals are also required to obtain all relevant information of an "important" attendants so that to be used by a "prophet" during his prophecy. Through these honest services, a "prophet" establishes his fame and trust; and those individuals share from economic and other benefits that come from attendants. Pride/Fame or trust seeking corruption is, therefore, a religious corruption committed between leaders of that institution and those individuals close to him.

\section{Corruption in Contributions from Followers}

This form of corruption differs from the "Gospel of Prosperity" type that this type is related with contributions normally required of scriptures. Followers of all studied religious institutions allege that they know nothing about the money that they contributed in the form of one/tenth and other contributions. This less transparent utilization of the money and other contributions clearly show corruption associated with these contributions. Many have stated that religious leaders are often condemned of corrupting such contributions. These days, religious leaders are wealthy and the possible source of their wealth is corrupt utilization of these contributions. While purchasing church seats, a priest of a certain church has informed the cashier to state much more money in the receipt than actually paid. Many followers also allege that contributions to religious institutions are not subject to normal accounting system, and leaders of the respective institutions administer them in the way they deem proper. This has created a great loophole to this corruption.

\section{Corruption in Election of Religious Leaders}

Corruption paid to some influential followers by candidates to religious leadership to convince the mass to elect or not to elect certain candidate is also common in the study area. Those persons competing for religious leadership often pay followers to elect them, and promise to pay if they abstain from electing their opponents. Recently, this sort of corruption is becoming a common practice in almost all religious institutions. Engaging in corrupting voters to win religious leadership also imply existence of undue benefit (corruption) the candidate expects if she is elected to that post. This practice also affirms the above discussed allegations that religious leaders are highly corrupt these days.

\subsection{Regulating Unregulated Corruption: Justifying a State Intervention}

So far, we have seen that there is widespread corruption in the purely private sector and religious institutions. It has become clear from the previous discussions that this corruption is not regulated. Important question at this juncture, therefore, is should this unregulated corruption be regulated? And who may regulate it if regulation is needed? 


\subsubsection{Arguments against a State Intervention}

There is a strong argument that corruption in purely private businesses and religious institutions should not be a state business; as a state and these institutions are independent of one another (FDRE, Proc. No. 1/1995). More strongly, it has been argued that state intervention in purely private sector violates the principle of marketism that advocates for non-interference of a state in the market as, in normal conditions, a market can perfectly function by itself. Likewise, it is commonly argued that a state's intervention in religious institutions clearly amounts to violation of the principle of secularism, the principle that advocates for separation of state and religion, thereby dictating that a state should not interfere in religious matters and the religion should also not interfere in state affairs (Ibed).

\subsubsection{The Need and Justifications for State Intervention}

Equally strong arguments are also forwarded supporting a state intervention to combat corruption in these sectors. The following are core arguments forwarded as found out by this research. This writer has theorized these arguments as follows.

\section{"Similar Effects" Justification}

Corruption anywhere is corruption everywhere. It is generally accepted that corruption in public sector seriously affects human life. It affects development plans and performances, quality of service including basic services such as health and education. Corruption is also recently termed as a violation of human rights (The UN, UNCAC 2004) as it ultimately results in deaths, illness, poverty and likes. If these and other effects of corruption in public sector is admitted, corruption in private and religious sectors cannot be an exception, except the possible difference in intensity of its effects (as corruption in these sectors might involve less funds compared to public sector corruptions). This allegation is admitted by many scholars and even by the UN General Assembly when it has made a private corruption a core issue in its anticorruption moves. Precisely, likewise public sector corruption, corruption in religious institutions and purely private sectors affect human life in many forms that may result in unbearable consequences. Therefore, equally, there is reasonable cause to deal with corruption in these sectors of a society. To mitigate consequences of these effects, therefore, a state intervention in private and religious sector is justified. If acts with similar effects are dealt with in the public sector, there cannot be a convincing reason why the same acts in these sectors should not be dealt with.

\section{"A State Protective Duty" Justification}

As stated above, unregulated corruption in religious institutions and private businesses has extremely affected interests of religious followers, business customers and business persons. Religious followers, for example, are exploited by religion leaders in many forms. What was termed as "commercial corruption" may also hinder entrepreneurship and creativity, both in businesses and industries. As noted shortly, recently corruption is being approached as human rights violation; and it at least violates right to corruption free society. These all effects 
either directly or indirectly affect individual citizens involved in those transactions. In other words, ultimate bearers of negative effects of corruption in these sectors are an individual citizen. It is fully agreed that one of a state's duties is a duty to protect its citizens from unnecessary exploitation, irrespective of a perpetrator. If corrupt perpetrators (religious leaders, employers, labor unions representatives and likes) are exploiting citizens, the same logic strongly calls for a state intervention in order to protect those affected by such corruption. This is an ordinary duty of any state (FDRE, Proc. No. 1/1995).

Those who argue against this justification state that a state duty to protect citizens, and hence interventions on this ground can be justified only if there is coercive exploitation. If a citizen alleged to have been exploited has surrenders herself willingly, there is no need for a state intervention. Religious followers particularly contribute willingly, and many are happy to do so. No one coerces them. They involve themselves in all the said activities on the voluntary basis. Where, then can be sound reason for state intervention? Anti-state interventions argue that any such type of intervention might amount to paternalistic intervention, where a state is presumed to have known what is good for its citizens and empowered to dictate the same. This approach clearly undermines religious followers rationality. Therefore, they conclude, a state intervention under guise of citizen protection is unjustified as it undermines rational faculty of followers.

Two reasons, however, outweigh anti-interventionists argument. For one thing, recent development in corruption is that it violates human rights (Gebeye, 2011; The UN, UNCAC, 2004), minimum right violated in all corruption cases being right to corruption free society (Kale, 2000). Human rights principles dictate states to avert human rights violation in the society, whatsoever its sector may be (FDRE, Proc No. 1/1995; FDRE, Proc. No. 210/2000). A state, for instance, cannot stay neutral if human rights violation has happened in a religious institution. It is not a sound argument to object a state intervention if any religious practice results in a cruel or inhuman treatment of followers; for a state has a duty to halt such cruelty or inhumanity in a religious sector. In short, state is duty bound to intervene in religious practices if such practices are considered as a human rights violation (Ibid). This takes us to the conclusion that; if corruption is human rights violation, whatever intervention by a state in whichever sector is automatically justified.

The second argument is that corruption everywhere is committed with full knowledge and consent (the reason why most anticorruption laws presume existence of mensrea). In this regard, religious corruption cannot be an exception. If a state is justified in dealing with willingly committed corruption in public and private sectors, similar intervention in religious sector is justified by the same reasoning.

"Right to Corruption Free Society" Justification

Corruption affects human rights in many ways. The important development in linking corruption and human rights is that it violates a citizen's right to 
"corruption free society" (Kale, 2000). This is a right introduced to take anticorruption moves to the highest level. The whole essence of this right is that corruption offends many citizens, even if they are not directly affected by that specific corrupt act. A mere existence of a corruption in a society suffocates individuals who hate corruption. Accordingly, they, in order to be relieved of such suffocations, should be provided with corruption free environment. This environment can be claimed only if their right to corruption free environment is duly recognized. This right, therefore, is introduced to protect individuals who hate even a mere existence of corruption in a society. Corruption free society right dictates that every sector of a given society must be free of corrupt acts and behaviors. Bring this to a case of religious corruption, not only a follower of that religion, but also non followers will have a full right to demand combating religious corruption. Religious sector being one sect of a society, everyone-followers and non followers-has a right to have it free of corruption. Therefore, it is a duty of a state to deal with violation of "corruption free society" right of all citizens. On this basis, therefore, a state can intervene in religious and private sector corruptions to carry out its duty of enforcing citizens' rights.

"Demand for Effective Corruption Fight" Justification

Anticorruption activities must be effective. Effective control of corruption demands effectiveness in all three anticorruption measures, i.e. realizing attitudinal change, investigating corrupt practices and prosecuting the same. One thing that can seriously affect effectiveness of these measures is existence of unregulated corruption in some sects of a society. People engage in different sector of a society in a different capacity. A religious follower in religious sector can be public office holder in a public sector, and even a businessman in a private sector. He may interact in different sectors in different capacity. He may carry his behavior in one sector to his interaction in another sector. If this man is exposed to corrupt attitudes in a sector where corruption is not regulated, he may bring this attitude to a sector where a corruption is strictly dealt with, and the vice-versa. Practices in studied area show that there is a rampant corruption in religious and private sectors where people may freely engage in corrupt acts. This rampant corruption proves that people are not carrying their anticorruption experiences in public sector to these sectors. Therefore, it can be said that they are rather carrying their corrupt attitudes to sectors where corruption is dealt with. This practice clearly contributes to widespread corruption in public sectors, rendering anticorruption moves ineffective. Therefore, a state should intervene in religious and private sectors to deal with corruption that is rendering its anticorruption efforts ineffective.

\section{"Use of Power" Justification}

Regulating corruption involves anticorruption education, investigating and prosecuting corrupt acts and restoring properties obtained via corruption. The last three acts of these regulatory measures involve use of power. An institution dealing with corruption, therefore, should possess investigative, prospective and 
restorative power. These are powers exclusively vested in a state. Accordingly, a state alone can regulate unregulated corruption in religious and private sectors. If left to the sectors-or actors in those sectors-the only measure they can take is an educative one; which cannot effectively contribute to combating corruption in the sectors. Therefore, a state should intervene in these sectors with all its powers that well equip it to effectively fight against corruption.

\section{Conclusion}

There are widespread unregulated corruption and corrupt behavior in religious and private institutions that are not covered by anticorruption laws of Ethiopia. This unregulated corruption and behavior is revealed through acts of bribing agents and employees of others and labor union representatives, corruption in sport activities, private recruitment corruption, gospel of prosperity and bribing God, favoritism, and cheating religious contributions and the likes. These acts and behaviors violate human rights of different individuals, affect state development plans, influence state's anticorruption efforts in general and an effort of achieving attitudinal change in particular, thereby encouraging corruption and corrupt behaviors.

These effects demand a state intervention in these sectors with the view of controlling corruption. A state intervention is demanded against the established principles of "Market Freedom" and "Secularism", i.e. separation of a state and religion. Corruption being abnormality in market, the principle that advocates for market freedom whenever a market operates in a normal condition, lacks a logical justification for objecting a state intervention. Similarly, the principle of secularism that advocates for non-state intervention in religious affairs also would be short of convincing explanation for preventing a state intervention in religious institutions with the view of combating corruption. This is so, because corruption in religious institutions cannot be religious affair that justifies applicability of secularism principle; and more importantly, secularism cannot provide genuine reasons to deny access to a state intervention that aims at ending human rights violation in religious institution that is committed in the form of corruption. Therefore, there is a clear and justified demand to regulate unregulated corruption in religious institutions and private sector in Ethiopia by expanding scopes of anticorruption laws of the Country.

\section{Acknowledgements}

I would like to extend my heartfelt thanks to those who have continuously insisted me to finish this work. Special thanks go to my colleagues who have encouraged me to advance my academic career.

\section{Conflicts of Interest}

The authors declare no conflicts of interest regarding the publication of this paper. 


\section{References}

Adebimpe, A. A., \& Ayodeji, O. S. (2014). Religious Values and Corruption in Nigeria-A Dislocated Relationship. Journal of Educational and Social Research, 4, 522.

Faleye, O. A. (2013). Religious Corruption: A Dilemma of the Nigerian State. Journal of Sustainable Development in Africa, 15, 170-185.

Gebeye, B. A. (2011). Rethinking International Anti Corruption Conventions: Advancing Corruption-Free Service as a Human Right. An LL.M Thesis, Addis Ababa University School of Law.

Kale, N. K. (2000). The Right to a Corruption-Free Society as an Individual and Collective Human Right: Elevating Official Corruption to a Crime under International Law: The International Lawyer. The American Bar Association's Section of International Law and Practice, 34, No. 1.

Kumar, C. R. (2004). Human Rights Approaches of Corruption Control Mechanism: Enhancing the Hong Kong Experience of Corruption Prevention Strategies. San Diego International Law Journal, 5, 323-351.

Marquette, H. (2010). Corruption, Religion and Moral Development: Religions and Development Research Programme. Working Paper 42, Birmingham: International Development Department, University of Birmingham.

Ochulor, C. L., \& Bassey, E. P. (2010). Analysis of Corruption from the Ethical and Moral Perspectives. European Journal of Scientific Research, 44, 466-476.

Painter, R. W. (2006). Ethics and Corruption in Business and Government: Interdependence and Adverse Consequences. Chicago: Law School of Chicago University. http://chicagounbound.uchicago.edu/fulton_lectures

R. D. R. (1960). Control of Nongovernmental Corruption by Criminal Legislation. University of Pennsylvania Law Review, 108, 848-867. https://doi.org/10.2307/3310456

Raj Kumar, C. (2008). Corruption, Development and Good Governance: Challenges for Promoting Access to Justice in Asia. Michigan State Journal of International Law, 16, 475.

Stückelberger, C. (2010). Corruption-Free Churches Are Possible: Experiences, Values, Solutions. Geneva: Globethics.net.

Tamyalew, A. (2010). A Review of the Effectiveness of the Federal Ethics and Anticorruption Commission of Ethiopia. European Union and the International Bank for Reconstruction and Development/The World Bank.

Tessema, M. T., \& Koen, R. (2017). The Problem of Private-to-Private Corruption. Journal of Anticorruption Law, 1.

The Constitution of the Federal Democratic Republic of Ethiopia Proclamation No. 1/1995.

The Corruption Crimes Proclamation No. 881/2015.

The Criminal Code of the Federal Democratic Republic of Ethiopia (FDRE) Proclamation No. 441/2005.

The Ethiopian Human Rights Commission Establishment Proclamation No. 210/2000.

The Federal Ethics and Anti-Corruption Commission Establishment Proclamation, Proc. No. 235/2001.

The Revised Federal Ethics and Anti-Corruption Commission Establishment Proc. No. 433/2005.

The Revised Federal Ethics and Anti-Corruption Commission Establishment (Ammend- 
ment) Proclamation No. 883/2015.

The UN (2004). United Nations Convention against Corruption. United Nations Office on Drugs and Crime, Vienna.

You, J.-S., \& Khagram, S. (2005). A Comparative Study of Inequality and Corruption. American Sociological Review, 70, 136-157.

https://doi.org/10.1177/000312240507000107 